\title{
Title: HPV vaccination and sexual health in France: empowering girls to decide
}

\author{
Authors: Hervé LEFEVRE ${ }^{a, b, c}$, herve.lefevre@aphp.fr, MD, Stéphanie SAMAIN ${ }^{a, d}$, \\ stephaniesamain@hotmail.com, Nour IBRAHIM ${ }^{a, b, c, d}$, nour.ibrahim@aphp.fr, MD, Christine \\ FOURMAUX c,e, christine.Fourmaux@chicreteil.fr, MD, Anne TONELLI, \\ anne.tonelli@fsef.net, MD, Sébastien ROUGET ${ }^{\mathrm{c}, \mathrm{g}}$, sebastien.rouget@chsf.fr, MD, \\ Emmanuelle MIMOUN ${ }^{c, h}$, emmanuelle.mimoun@ch-marchant.fr, MD, Renaud DE \\ TOURNEMIRE ${ }^{c, i}$, rdetournemire@chi-poissy-st-germain.fr, MD, Marie DEVERNAY, ${ }^{c, j}$, \\ marie.devernay@aphp.fr, MD, Marie Rose MORO ${ }^{a, b, d}$, marie-rose.moro@aphp.fr, MD, PHD, \\ Jonathan LACHAL ${ }^{\mathrm{a}, \mathrm{b}, \mathrm{d}}$, jonathan.lachal@gmail.com, MD, PHD \\ Affiliations: ${ }^{a}$ AP-HP, Cochin Hospital, Maison de Solenn, Paris, France. ${ }^{b}$ CESP, Fac. de médecine - \\ Univ. Paris-Sud, Fac. de médecine - UVSQ, INSERM, Université Paris-Saclay, 94805, Villejuif, France. ${ }^{c}$ \\ French Clinical Research Group in Adolescent Medicine and Health. ${ }^{d}$ Université Paris Descartes, \\ Sorbonne Paris Cité, Paris, France. ${ }^{e}$ Unité de médecine de l'adolescent $\mathrm{CHI}$ Créteil, France. ${ }^{\mathrm{f}}$ Service \\ de médecine interne pour adolescence, clinque E.Rist, Paris, France. ${ }^{\mathrm{g}}$ Service de pédiatrie Centre \\ Hospitalier Sud-Francilien, Corbeil, France. ${ }^{h} \mathrm{CH}$ Marchant, Toulouse, France. ${ }^{i}$ Unité de Médecine \\ pour Adolescents CHI Poissy St Germain en Laye. ${ }^{j}$ AP-HP, Trousseau Hospital, unité pour adolescents, \\ Paris France
}

Corresponding author: Dr Jonathan LACHAL, CESP - INSERM 1178, Maison des Adolescents, 97 Boulevard de Port Royal, 75679 PARIS CEDEX 14, France, Phone: +33614149002, Jonathan.lachal@gmail.com 


\section{Title: HPV vaccination and sexual health in France: empowering girls to decide 2 Background}

3 Forty serotypes of human papilloma virus (HPV) are associated with the risk of genital infection and

4 around 15 with the risk of cervical cancer [1]. This virus responsible for 2800 cases of cervical cancer

5 and more than 1000 deaths in France each year [2] and for 630,000 new cases of cancer worldwide

6 per year [3]. Vaccination against it is, together with cervical screening, the means of preventing most

7 of these cancers [4]. HPV vaccination has been available since 2007 for the prevention of cervical and

8 other genital cancers in France. The two vaccines (HPV 4, 2) available at the time of our study protect

9 against serotypes 16 and 18, which are linked to 70\% of these cancers [5]. In August 2018, a third

10 vaccine - HPV 9, a nonavalent vaccine protecting against an additional five serotypes - became

11 available in France. It thus covers seven serotypes responsible for over $90 \%$ of cervical cancers [6].

Health policies and legislation about vaccination and vaccine access vary quite substantially between high income countries. Consequently, coverage rates range from very low $(<20 \%)$ to very high (>85\%). Countries with a national vaccination program most often at least reach the minimum rate of $50 \%$, while countries offering so-called "opportunistic" vaccination (a very limited number of mandatory vaccinations, with physician encouragement about other recommended vaccines whenever the opportunity arises) most often have rates substantially below that [7-11]. French HPV vaccination coverage is extremely low $(<20 \%)$, especially because of the paradoxical role of doctors who must defend the benefits of vaccination about which they are not entirely convinced [12].

Teenage girls today are increasingly involved in the medical care that concerns them, and it appears useful to ask what they know about this vaccine. Few studies in France or elsewhere have examined this question [13-17]. All of them, however, report a lack of knowledge and information about the risk of this infection and the effectiveness and safety of the vaccine, even in countries with high vaccination coverage $[15,17-19]$. Girls most often appear to be relatively unconcerned about access to either information or the vaccine, even though they are directly involved $[20,21]$. Finally, in France 
1 they are paradoxically excluded from the decision about this vaccination, given the requirement for

2 parental authorization, even though they can obtain contraceptives and an elective abortion, as well

3 as treatment for sexually transmitted infections, without their parents' agreement [22]. In this

4 French context, which is paradoxical at several levels, an in-depth exploration of adolescent girls'

5 experiences with this vaccination appears useful to improving our understanding of their role in the

6 decision about whether or not to be vaccinated.

\section{Method}

8 We conducted a multicenter qualitative study in six medical centers specialized in adolescent care

9 (Corbeil, Créteil, Paris 14, Paris 16, Poissy, and Toulouse). An appropriate ethics review board 10 approved the protocol.

\section{Participants}

We included adolescent girls who consented to participate, with their parents' consent. They could be inpatients or outpatients and were aged from 11 through 19 years. Because our goal was to explore rather than test their knowledge about this vaccination, we chose a clinical population, assuming that they were better informed and more involved in medical care than the general population. Accordingly, they would have more explicit positions, which would facilitate our exploration.

\section{Data extraction}

The girls and their parents received information about our research project and provided written consent. We then asked the girls to answer one yes/no question ("have you been vaccinated against HPV?") and to respond to the following essay question: "What do you know about vaccination against HPV? What is it for? Depending on whether or not you are vaccinated, what was your decision based on? What might have made this choice complicated? Write what you know about this subject for the next 20 minutes. Our researchers will study what you wrote to enable them to have a 
1 better understanding of teenage girls' point of view about this vaccination". The relatively long

2 response period should have allowed the teens to draft a text of at least several lines. When the text

3 was particularly relevant because of an original perspective, broad knowledge on the topic, or an

4 interesting suggestion, we recontacted the teenage girl to conduct an individual free interview to

5 explore the relevant points raised in her writing. All five girls asked to participate agreed. One

6 researcher trained in semi-structured interviews conducted all the interviews (SS). The interviews

7 lasted one hour, took place in the medical unit, and were recorded. All the data - interviews, and

8 handwritten responses- were transcribed verbatim and included in the qualitative analysis.

\section{Data analysis}

10 We conducted two different types of qualitative analyses: the first applied the principles of 11 interpretative phenomenological analysis (IPA) [23], using no computer assistance, while the second 12 used ALCESTE ${ }^{\circledR}$ software (Analyse des Lexèmes Co-occurents dans un Ensemble de Segments de Textes, or Analysis of Co-occurring Lexemes in a Set of Text Segments) [24].

We began with IPA and constructed a thematic framework from independent analyses by two researchers ( $\mathrm{HL}$ and $\mathrm{JL})$. The entire research team met repeatedly to discuss these results. The entire dataset, that is, the transcripts of all essays and all interviews, was repeatedly read and then coded to identify initial themes, which were annotated in the margins. Recurrent themes were then identified across transcripts. This stage involved a more analytical ordering, as we tried to make sense of the connections between themes. Some of the themes tended to cluster. The process was dynamic and cyclic, with each transcript leading to the collection and analysis of further data, which could modify previous results. The aim was to recognize ways in which narratives from the participants were similar but also different. The last stage was to produce a coherent ordered table of the themes [23].

Next we analyzed the textual data, using the statistical clustering procedures encoded in ALCESTE ${ }^{\circledR}$ software. ALCESTE is not hypothesis-driven. It constructs an overview of patterns found in the text 
1 (classes) according to how often roots and word forms appear together, for example, by performing

2 different types of hierarchical descending classifications. It does not quantify the text, but simply

3 counts repetitions of associations of words sufficiently close together and thus enabled us to

$4 \quad$ construct groups of words to be interpreted as themes by the researchers.

5 Finally, the results of each analysis were compared, and the ALCESTE-assisted findings were used to

6 refine the IPA-generated categories. Classes were connected to themes when it made sense, and

7 themes were reorganized to consider the additional or new meaning provided by the software

8 analysis. If no theme could be connected to a text class, a new theme could be constructed.

\section{Results}

\section{Characteristics of the adolescent girls}

11 In all, 101 teenage girls ( $80 \%$ of those asked to participate) completed the essay question. Their mean 12 age was 15.5 years (range: 11-19). Half were receiving outpatient care, and half were inpatients. In all, $1324 \%$ reported they had been vaccinated against HPV. Five girls were enrolled in a semi-structured 14 interview (Table1).

\section{ALCESTE analysis}

16 A total of 10,216 words were analyzed, corresponding to 1292 unique shapes distributed in 284

17 elementary contextual units (ECU). The software classified $76 \%$ of the corpus into four lexical classes. Two different hierarchical descending analyses revealed a dendrogram containing four classes (Figure

19 1). Classes 3 ("active decision") and 4 ("factual knowledge") were closely linked together; they were also linked, but less closely, with Class 2 ("information"). Class 1 ("motives and obstacles") was separate from the others. These different classes made it possible to confirm and reinforce the themes constructed in the phenomenological analysis (Table 2). 


\section{$1 \quad$ Thematic analysis}

2 We decided to organize our results around four superordinate themes: The teenage girls' factual

3 knowledge about vaccination, their motives for and obstacles to vaccination, their involvement in the decision about vaccination, and finally the need for information about and solutions to this issue (Table

$53)$.

\section{Adolescents' factual knowledge about vaccination}

7 The main thing that the girls knew about vaccination against HPV was its principal indication:

8 prevention of the risk of cervical cancer. Some adolescents associated this risk more precisely with

9 that of an infection that occurs during sexual intercourse and is prevented by vaccine immunization

10 against HPV. They are aware of its recommended - and therefore not mandatory - nature as well

as that the indication is reserved for girls, and they never questioned this point. Their knowledge was otherwise more vague about the type of cancer associated with HPV, the vaccination schedule, and the mode of transmission. The mode of HPV transmission or the indication for vaccination against it were sometimes described by somewhat fantastical remarks: quite often, the girls knew nothing about the virus or the vaccine, regardless of their vaccination status.

\section{Motives for and obstacles to vaccination}

The principal reasons in favor of vaccination against HPV were adolescent girls' general interest in their health and the prevention of the risk of HPV transmission during sexual relations as well as of its risks of cancer, and death. The non-mandatory nature of this vaccination requires that individuals develop their own personal reasons to have it. and worries. 
1 nonetheless remains essentially hypothetical for the girls and frightening for the parents. The

2 presumed association between HPV infection and at-risk sex makes the need for the vaccine still

3 more hypothetical.

4 Teenaged girls clearly feared side effects associated with the HPV vaccine: these complications were

5 sometimes described as serious and could cause them to be worried or even to oppose vaccination.

6 Some adolescents considered that side effects are uncertain, but they have heard rumors, and they

7 feel that prudence requires them to step back from this vaccine perceived as too recent.

8 Finally, the girls mentioned the fear of injections and their pain, complicated family contexts -

9 including family history of autoimmune or degenerative neurological diseases -, or even the cost of the vaccine.

\section{Adolescents' involvement in the vaccination decision}

Decision-making about vaccination always involves an active choice by the girl, whether it is positive or negative, complicated or simpler. While the choice most often responds to the parents' expectations or the doctor's recommendation, girls looking for autonomy, independence, actively appropriate the decision. This active position therefore appears at a later point, most often after passive indifference and submission to the choice imposed by the parents. Vaccinated girls were more involved in the decision and more frequently shared arguments for or against HPV vaccination than nonvaccinated girls.

\section{The need for information and solutions}

The teenage girl's lack of involvement at the time of the decision is associated in her discourse with lack of personal knowledge about vaccination. Doctors are the principal source of information, but they do not always routinely offer vaccination and what they have to say is not always sufficient to answer girls' questions. 
1 Many teenage girls formulated requests for information about vaccination generally and that against

2 HPV in particular, so that they could form their own opinion about how the vaccine was discovered, its

3 indication, effectiveness, and risks. This should enable them to participate in the decision about

$4 \quad$ whether or not to be vaccinated.

5 They thus made suggestions to improve the information they receive, pointing first to the school

6 setting (teachers and preventive medicine). They underlined the feeble impact of poster campaigns in

7 health centers or mail campaigns. They asked for information via media addressed to young people

8 (television, internet) and at meeting places at vaccination sites.

\section{Discussion}

Our study looked at the perspectives about HPV vaccination of adolescent girls receiving medical care as out- or in-patients at a French hospital. The principal finding is the girls' lack of knowledge about this vaccination. The knowledge that some of them have is insufficient to allow them to be involved in an individual decision for which they can assume responsibility.

Numerous countries with high vaccination coverage against HPV organize mandatory vaccination programs, most often in school settings [14]. The question of individual choice here gives way to the collective benefit. In this case, if the information is not always judged sufficient, vaccination appears nonetheless a normative process: vaccination becomes the rule. Contrary to other vaccinations that France made mandatory for infants in 2018 [25], the government continued its opportunistic vaccination system for HPV, based on individual decisions and, for those younger than 18 years, subject to parental authorization. This system requires that the person concerned or the decisionmaker have sufficient individual motivation. Two issues are thus presented: the first is that of the girl herself. Well-informed, she can play an active role in the vaccination decision $[13,15,17]$. The other is the role of the parents, who currently must agree to their daughter's vaccination $[14,26,27]$.

The difficulties in providing information on the subject of this vaccine are well known $[17,20]$. Societal suspicion, taboos about sex, prejudices about the association between infection and (at-risk) 
1 sex, or the fear of side effects in today's climate of vaccination controversies [19,28-30] - all these

2 can become confused with the fear of injection or of the pain associated with vaccination, or even its

3 cost for families without supplementary health insurance $[15,17,18]$. These factors are all part of the

4 emotional discourse around vaccination, which guides decisions much more than rational discourse

5 does [31,32]. To counter emotions, information should be repeated and brought closer to these girls'

6 preoccupations. The young people questioned proposed that more systematic, more regular

7 information be organized, in appropriate settings, such as schools or vaccination centers. Its

8 pedagogical content must focus on this virus, the disease pathogenesis, and the possible methods of

9 prevention. The information should allow girls to develop their own opinion in middle school, according to their own rhythms, and to feel more concerned by the issue. It appears useful to integrate the discourse about HPV vaccination with the general discourse about sexual health prevention of sexually transmitted disease as well as discourse about sexual health [33]. This would make it possible to move away from talking about the prevention of a hypothetical and distant cancer that does not correspond at all to the concerns of adolescents, which are much more shortterm, set as they are in the immediate or near future.

This raises the question of parental involvement in the vaccination decision. Parental fears have been identified as one of the principal obstacles to vaccination $[14,27,28,34]$. The vaccine is recommended at an age where adolescents are becoming increasingly involved in the medical decisions that concern them $[17,26]$. It is noteworthy that HPV vaccination for girls in France younger than 18 years requires parental approval, although the girls can make a substantial number of the decisions about their sexual health without parental accord: contraception and morning-after pills, elective abortions, and screening and treatment of sexually transmitted infections. Moreover, these types of care can be performed for minors both anonymously and free of charge. We propose that vaccination against HPV be added to the list of potential rights for young girls guaranteed by French law. The laws about decisions and access to care related to adolescent sexual health differ from country to country and within subdivisions of countries; they are often more restrictive than in 
1 France [35]. Many countries are more permissive about minor girls making the decision about HPV

2 vaccination, although agreement with parents is most often sought. We hope that legislative

3 progress will allow young girls to be more deeply involved in these decisions. If girls are well-

4 informed and participate actively in the decision, it becomes possible to envision individual

5 awareness that will progressively lead to protection of the entire community.

\section{Strengths and limitations of the study}

7 We questioned more than 100 French adolescent girls about vaccination against HPV. This was a 8 clinical population, seeing doctors regularly, and possibly better informed about this vaccination.

9 Nonetheless, these French teenage girls with a chronic disease did not have optimal vaccination 10 coverage, although their rate of complete vaccination is higher than in the general population [36].

11 Finally, even though the representativeness of the general population is not an aspect defining rigor 12 in qualitative research, our sample is representative of the different theoretical positions, with 13 variability of age, vaccination status, and social and demographic backgrounds.

\section{Conclusion}

Teenage girls are more sensitive to the emotional discourse that surrounds HPV vaccination than to rational knowledge about it. The requirement for parental authorization to be vaccinated reinforces the girls' lack of investment. Vaccination programs should integrate the HPV vaccine into sexual health education and send a strong signal by offering vaccination that is anonymous and free of charge, as already possible in France for requests for other sexual health care.

\section{Acknowledgments}

We would like to thank the adolescents who participated in the study, the members of the Groupe français de recherche clinique en médecine et santé de l’adolescent (French Clinical Research Group in Adolescent Medicine and Health), and Jo Ann Cahn for the translation. 


\section{Competing interest}

2 All authors have completed the ICMJE uniform disclosure form at www.icmje.org/coi_disclosure.pdf

3 and declare: no support from any organisation for the submitted work; no financial relationships with

4 any organisations that might have an interest in the submitted work in the previous three years; no

5 other relationships or activities that could appear to have influenced the submitted work.

\section{$6 \quad$ Funding}

7 This research did not receive any specific grant from funding agencies in the public, commercial, or

8 not-for-profit sectors.

\section{Authors' Contributions}

Conceived and designed the experiments: $\mathrm{HL}, \mathrm{SR}, \mathrm{AT}, \mathrm{RDT}, \mathrm{CF}, \mathrm{AC}, \mathrm{MD}, \mathrm{MRM}, \mathrm{JL}$

Conducted the literature review: SS, NI

Performed the experiments: $\mathrm{HL}, \mathrm{SS}, \mathrm{NI}, \mathrm{SR}, \mathrm{AT}, \mathrm{RDT}, \mathrm{CF}, \mathrm{AC}, \mathrm{MD}$

Wrote the paper: $\mathrm{HL}, \mathrm{SS}, \mathrm{MRM}, \mathrm{JL}$ (the entire paper), SR, AT, RDT, $\mathrm{CF}, \mathrm{AC}, \mathrm{MD}$ (results and discussion), $\mathrm{NI}$ (introduction and discussion).

Final Approval: $\mathrm{HL}, \mathrm{SS}, \mathrm{NI}, \mathrm{SR}, \mathrm{AT}, \mathrm{RDT}, \mathrm{CF}, \mathrm{AC}, \mathrm{MD}, \mathrm{MRM}$, and JL

All authors had full access to all of the data in the study and take responsibility for the integrity of the data and the accuracy of the data analysis.

The manuscript is an honest, accurate, and transparent account of the study being reported; no important aspects of the study have been omitted; and any discrepancies from the study as planned have been explained.

\section{Tables and Figure}

Table 1 - Characteristics of the young women interviewed

Table 2 - Descriptions of classes and associated themes 


\section{References} 3663-z. 313887.

Table 3 - Direct quotations from participants' interviews and questionnaires

Figure 1 - Dendrogram of the classification of ECUs: two descending hierarchical classification with the percentage of ECUs classified and created by ALCESTE software

[1] Viens L, Henley SJ, Watson M, Markowitz LE, Thomas CC, Thompson TD, et al. Human Papillomavirus-Associated Cancers - United States, 2008-2012. MMWR Morb Mortal Wkly Rep 2016;65:661-6. doi:10.15585/mmwr.mm6526a1.

[2] Leone N, Voirin N, Roche L, Binder-Foucard F, Woronoff A, Delafosse P, et al. Projection de l'incidence et de la mortalité par cancer en France métropolitaine en 2015. Saint Maurice: Institut de veille sanitaire; 2015.

[3] de Martel C, Plummer M, Vignat J, Franceschi S. Worldwide burden of cancer attributable to HPV by site, country and HPV type: Worldwide burden of cancer attributable to HPV. Int J Cancer 2017;141:664-70. doi:10.1002/ijc.30716.

[4] Schiffman M, Castle PE, Jeronimo J, Rodriguez AC, Wacholder S. Human papillomavirus and cervical cancer. The Lancet 2007;370:890-907. doi:10.1016/S0140-6736(07)61416-0.

[5] Muñoz N, Bosch FX, de Sanjosé S, Herrero R, Castellsagué X, Shah KV, et al. Epidemiologic Classification of Human Papillomavirus Types Associated with Cervical Cancer. N Engl J Med 2003;348:518-27. doi:10.1056/NEJMoa021641.

[6] Riethmuller D, Jacquard A-C, Lacau St Guily J, Aubin F, Carcopino X, Pradat P, et al. Potential impact of a nonavalent HPV vaccine on the occurrence of HPV-related diseases in France. BMC Public Health 2015;15. doi:10.1186/s12889-015-1779-1.

[7] Gottvall M, Tydén T, Larsson M, Stenhammar C, Höglund AT. Challenges and opportunities of a new HPV immunization program perceptions among Swedish school nurses. Vaccine 2011;29:4576-83. doi:10.1016/j.vaccine.2011.04.054.

[8] Hofman R, de Bekker-Grob EW, Richardus JH, de Koning HJ, van Ballegooijen M, Korfage IJ. Have Preferences of Girls Changed Almost 3 Years after the Much Debated Start of the HPV Vaccination Program in the Netherlands? A Discrete Choice Experiment. PLoS ONE 2014;9:e104772. doi:10.1371/journal.pone.0104772.

[9] Rondy M, van Lier A, van de Kassteele J, Rust L, de Melker H. Determinants for HPV vaccine uptake in the Netherlands: A multilevel study. Vaccine 2010;28:2070-5. doi:10.1016/j.vaccine.2009.12.042.

[10] Schülein S, Taylor KJ, König J, Claus M, Blettner M, Klug SJ. Factors influencing uptake of HPV vaccination among girls in Germany. BMC Public Health 2016;16. doi:10.1186/s12889-016-

[11] Bonanni P, Bechini A, Donato R, Capei R, Sacco C, Levi M, et al. Human papilloma virus vaccination: impact and recommendations across the world. Ther Adv Vaccines 2015;3:3-12. doi:10.1177/2051013614557476.

[12] Lefèvre $H$, Schrimpf $C$, Moro MR, Lachal J. HPV vaccination rate in French adolescent girls: an example of vaccine distrust. Arch Dis Child 2018;103:740. doi:10.1136/archdischild-2017-

[13] Cooper Robbins SC, Bernard D, McCaffery K, Brotherton JML, Skinner SR. "I just signed": Factors influencing decision-making for school-based HPV vaccination of adolescent girls. Health Psychol 2010;29:618-25. doi:10.1037/a0021449.

[14] Ferrer H, Trotter C, Hickman M, Audrey S. Barriers and facilitators to HPV vaccination of young women in high-income countries: a qualitative systematic review and evidence synthesis. BMC Public Health 2014;14:700. doi:10.1186/1471-2458-14-700. 
[15] Hilton S, Smith E. "I thought cancer was one of those random things. I didn't know cancer could be caught...": adolescent girls' understandings and experiences of the HPV programme in the UK. Vaccine 2011;29:4409-15. doi:10.1016/j.vaccine.2011.03.101.

[16] Hughes CC, Jones AL, Feemster KA, Fiks AG. HPV vaccine decision making in pediatric primary care: a semi-structured interview study. BMC Pediatr 2011;11:74. doi:10.1186/1471-2431-1174.

[17] Rambout L, Tashkandi M, Hopkins L, Tricco AC. Self-reported barriers and facilitators to preventive human papillomavirus vaccination among adolescent girls and young women: $\mathrm{A}$ systematic review. Prev Med 2014;58:22-32. doi:10.1016/j.ypmed.2013.10.009.

[18] Bernard DM, Robbins C, C S, McCaffery KJ, Scott CM, Skinner SR. The domino effect: adolescent girls' response to human papillomavirus vaccination. Med J Aust 2011;194:297-300.

[19] Kennedy C, Gray Brunton C, Hogg R. "Just that little bit of doubt": Scottish parents', teenage girls' and health professionals' views of the MMR, H1N1 and HPV vaccines. Int J Behav Med 2014;21:3-10. doi:10.1007/s12529-013-9356-4.

[20] Hendry M, Lewis R, Clements A, Damery S, Wilkinson C. "HPV? Never heard of it!": A systematic review of girls' and parents' information needs, views and preferences about human papillomavirus vaccination. Vaccine 2013;31:5152-67. doi:10.1016/j.vaccine.2013.08.091.

[21] Perkins RB, Chigurupati NL, Apte G, Vercruysse J, Wall-Haas C, Rosenquist A, et al. Why don't adolescents finish the HPV vaccine series? A qualitative study of parents and providers. Hum Vaccines Immunother 2016;12:1528-35. doi:10.1080/21645515.2015.1118594.

[22] Rey C. [Contraception and voluntary termination of pregnancy: legislative measures derogatory to parental consent in France]. Arch Pediatr Organe Off Soc Francaise Pediatr 2002;9:88-90.

[23] Smith JA. Interpretative phenomenological analysis. Qual. Psychol. Pract. Guide Res. Methods. 2nd ed., Sage Publications Ltd; 2008.

[24] Image. Alceste 2015 : Un logiciel d'analyse de données textuelles 2018.

[25] Lefèvre H, Moro MR, Lachal J. The New HPV Vaccination Policy in France. N Engl J Med 2018;378:1160-1160. doi:10.1056/NEJMc1801036.

[26] Chang J, Ipp LS, de Roche AM, Catallozzi M, Breitkopf CR, Rosenthal SL. Adolescent-Parent Dyad Descriptions of the Decision to Start the HPV Vaccine Series. J Pediatr Adolesc Gynecol 2018;31:28-32. doi:10.1016/j.jpag.2017.10.003.

[27] Holman DM, Benard V, Roland KB, Watson M, Liddon N, Stokley S. Barriers to Human Papillomavirus Vaccination Among US Adolescents: A Systematic Review of the Literature. JAMA Pediatr 2014;168:76. doi:10.1001/jamapediatrics.2013.2752.

[28] Gordon D, Waller J, Marlow LAV. Attitudes to HPV vaccination among mothers in the British Jewish community: reasons for accepting or declining the vaccine. Vaccine 2011;29:7350-6. doi:10.1016/j.vaccine.2011.07.083.

[29] Hopfer S, Clippard JR. College Women's HPV Vaccine Decision Narratives. Qual Health Res 2011;21:262-77. doi:10.1177/1049732310383868.

[30] Javanbakht M, Stahlman S, Walker S, Gottlieb S, Markowitz L, Liddon N, et al. Provider perceptions of barriers and facilitators of HPV vaccination in a high-risk community. Vaccine 2012;30:4511-6. doi:10.1016/j.vaccine.2012.04.062.

[31] Blume S. Anti-vaccination movements and their interpretations. Soc Sci Med 2006;62:628-42. doi:10.1016/j.socscimed.2005.06.020.

[32] Kata A. A postmodern Pandora's box: Anti-vaccination misinformation on the Internet. Vaccine 2010;28:1709-16. doi:10.1016/j.vaccine.2009.12.022.

[33] World Health Organization. Defining sexual health Report of a technical consultation on sexual health. Geneva: WHO; 2006.

[34] Katz ML, Reiter PL, Heaner S, Ruffin MT, Post DM, Paskett ED. Acceptance of the HPV vaccine among women, parents, community leaders, and healthcare providers in Ohio Appalachia. Vaccine 2009;27:3945-52. doi:10.1016/j.vaccine.2009.04.040.

[35] Amsellem-Mainguy Y. Contraception et grossesses à l'adolescence : vers une reconnaissance du droit à l'intimité des jeunes. Inf Soc 2011;165-166:156-63. 
1 [36] Gras-Le Guen C, Legrand A, Caquard M, Micaelli X, Picherot G, Lacroix S, et al. Chronically ill 2 3 adolescents are also incompletely vaccinated: A cross-sectional study in France. Vaccine 2017;35:4707-12. doi:10.1016/j.vaccine.2017.07.042. 


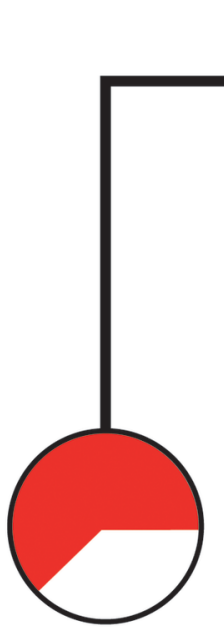

$64 \%$

Class 1

Motives and obstacles

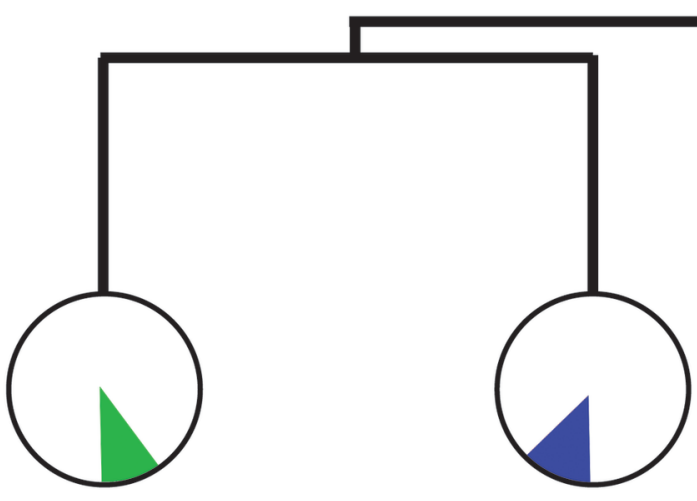

$8 \%$

Class 3

Active decision
$16 \%$

Class 4

Factual knowledge

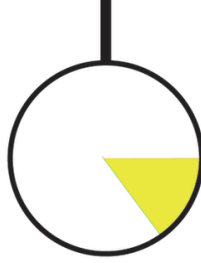

$12 \%$

Class 2 Information

Second hierarchical descending analysis

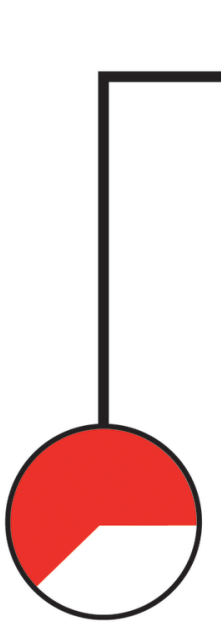

$64 \%$

Class 1

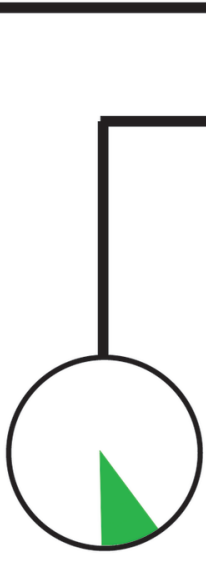

$8 \%$

Class 3

Active decision

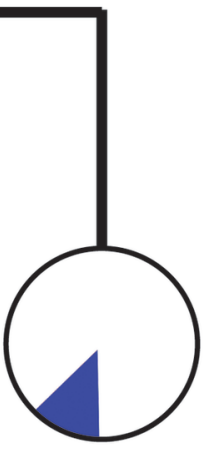

$16 \%$

Class 4

Factual knowledge

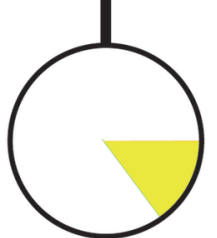

$12 \%$

Class 2

Information 
Table 1 - Characteristics of the young women interviewed

\begin{tabular}{|l|l|l|l|l|l|}
\hline ID & Age & School level & $\begin{array}{l}\text { Rural / } \\
\text { Urban }\end{array}$ & $\begin{array}{l}\text { Actual care } \\
\text { (inpatient/outpatient) }\end{array}$ & Main diagnosis \\
\hline ITW 1 & 14.5 & $8^{\text {th }}$ grade & urban & oupatient & Obesity \\
\hline ITW 2 & 18 & $12^{\text {th }}$ grade & urban & outpatient & Chronic pain \\
\hline ITW 3 & 17.5 & $11^{\text {th }}$ grade & urban & inpatient & Eating disorder \\
\hline ITW 4 & 15.5 & $10^{\text {th }}$ grade & urban & inpatient & Diabetes mellitus \\
\hline ITW 5 & 19 & 12 th grade & rural & inpatient & Eating disorder \\
\hline
\end{tabular}


Table 2 - Classes descriptions and associated themes

\begin{tabular}{|c|c|c|c|c|c|c|}
\hline & Title & $\begin{array}{l}\text { \% of the } \\
\text { Classified } \\
\text { ECUs }\end{array}$ & Typical words $\left(\chi^{2}\right)$ & $\begin{array}{l}\text { Antitypical } \\
\text { words }\end{array}$ & Description of the class and association with the theme & $\begin{array}{l}\text { Associated } \\
\text { theme }\end{array}$ \\
\hline Class 4 & $\begin{array}{l}\text { Factual } \\
\text { knowledge }\end{array}$ & 15.96 & $\begin{array}{l}\text { Anti-papillomavirus (66), } \\
\text { uterus (56), cervix (54), cancer } \\
\text { (48), serve (46), adolescent } \\
\text { (32), vaccinate (31), allow (27), } \\
\text { prevent (26), woman (24), } \\
\text { protect (22), sexual (19) }\end{array}$ & $\begin{array}{l}\text { Parents, } \\
\text { doctors, think }\end{array}$ & $\begin{array}{l}\text { The vocabulary/lexicon is very impersonal, exterior to the subject: the } \\
\text { vocabulary here is medical: vaccinate, cervical cancer, uterus. } \\
\text { The verbs are action verbs but are attributed to exterior objects: the } \\
\text { vaccine allows, protects, prevents. } \\
\text { The so-called factual knowledge about the vaccine is intellectualized. } \\
\text { Absence of the teen's emotional involvement. }\end{array}$ & $\begin{array}{l}\text { Adolescents' } \\
\text { factual } \\
\text { knowledge } \\
\text { about } \\
\text { vaccination }\end{array}$ \\
\hline Class 1 & $\begin{array}{l}\text { Motives and } \\
\text { obstacles }\end{array}$ & 63.85 & $\begin{array}{l}\text { Go (10), do (8), see (7), thing } \\
\text { (5), desire (5), take (5), } \\
\text { important (5), friend (4), sick } \\
\text { (4), school (3), middle school } \\
\text { (3), campaign (3), effective (3), } \\
\text { mandatory (3) }\end{array}$ & $\begin{array}{l}\text { Anti- } \\
\text { papillomaviru } \\
\text { s, uterus, } \\
\text { cancer, } \\
\text { cervix, } \\
\text { vaccinate }\end{array}$ & $\begin{array}{l}\text { The principal grammatical categories are markers of a temporal or } \\
\text { deductive or logical relation, or of intensity. It is the mark of a discourse } \\
\text { intended to convince, explain, and show how a personal position can } \\
\text { evolve over time. It is also the only class where "I or me" appears, which } \\
\text { shows the personal or intimate value of the words. } \\
\text { The emotional involvement is stronger and testifies to a reflective } \\
\text { pathway that will conclude by a choice (class } 3 \text { ). }\end{array}$ & $\begin{array}{l}\text { Motives for } \\
\text { and obstacles } \\
\text { to vaccination }\end{array}$ \\
\hline Class 3 & Active decision & 8.45 & $\begin{array}{l}\text { Complicate (102), choice (55), } \\
\text { know (14), think (13), negative } \\
\text { (9), positive (9) }\end{array}$ & Do, talk, go & $\begin{array}{l}\text { The vocabulary associates choice/decision with know, think, and } \\
\text { complicate, in discussing both positive and negative choices. } \\
\text { The grammatical categories represented most often are verbs and } \\
\text { function words, which show the active side of the discourse. } \\
\text { The decision is thus an active choice, underlying the teen's involvement. }\end{array}$ & $\begin{array}{l}\text { Adolescents' } \\
\text { involvement in } \\
\text { the vaccination } \\
\text { decision }\end{array}$ \\
\hline Class 2 & The information & 11.74 & $\begin{array}{l}\text { Hear (59), not much (23), talk } \\
(20) \text {, act (16), accept (16), say } \\
\text { (9), hesitate (9), youth (4), } \\
\text { parents (4), doctor (4) }\end{array}$ & $\begin{array}{l}\text { Do, disease, } \\
\text { mother }\end{array}$ & $\begin{array}{l}\text { The vocabulary brings together the verbs say, hear, talk to not say much } \\
\text { and people who talk about it, doctors, parents, and young people. The } \\
\text { markers of modelling are most present in this class. } \\
\text { The observation of lack of information lead the researcher and teen to } \\
\text { design solutions for better information }\end{array}$ & $\begin{array}{l}\text { The need for } \\
\text { information } \\
\text { and solutions }\end{array}$ \\
\hline
\end{tabular}


Table 3 - Direct quotations from participants' interviews and questionnaires

\begin{tabular}{|c|c|}
\hline \multicolumn{2}{|r|}{ Adolescents' factual knowledge about vaccination } \\
\hline $\begin{array}{l}\text { More or less specific } \\
\text { knowledge }\end{array}$ & $\begin{array}{l}\text { "I know that it's a vaccination against cervical cancer." ITW3 } \\
\text { "I don't know if I remember right if it's related to the uterus or the vagina." Essay question } \\
\text { "[This vaccination] isn't mandatory, but it is recommended." Essay question } \\
\text { "I think you need to have boosters for this vaccine several times over your lifetime." Essay question } \\
\text { "I know that the papillomavirus is a contagious virus and it is also sexually transmissible." Essay question } \\
\text { "It's a sexually transmitted diseases that girls get." ITW4 }\end{array}$ \\
\hline Fantastical ideas & $\begin{array}{l}\text { "It's a preventive vaccine just in case a dangerous butterfly stings you and you catch a virus." Essay question } \\
\text { "An important vaccine since you can catch these bacteria very easily in dirty toilets, for example." Essay question }\end{array}$ \\
\hline No knowledge & $\begin{array}{l}\text { "I've never heard of it." Essay question } \\
\text { "I didn't even know there was a vaccine against that." Essay question } \\
\text { "We're not really super-informed about vaccines, so we don't talk about it too much." ITW3 }\end{array}$ \\
\hline \multicolumn{2}{|r|}{ Motives for and obstacles to vaccination } \\
\hline $\begin{array}{l}\text { Personal and family } \\
\text { motives/reasons }\end{array}$ & $\begin{array}{l}\text { "All adolescents think about their health." Essay question } \\
\text { "Sexual relations are not rare in adolescence and it's better to be protected." Essay question } \\
\text { "Yes, I'd like to save my life, so yes, I'd like to be vaccinated!" ITW2 } \\
\text { "It's reassuring to tell yourself you're vaccinated because that reduces the risks of a dangerous disease that can prevent women from } \\
\text { experiencing the happiness of being a mother." Essay question } \\
\text { "My mother has talked to me about this vaccine a lot because she has papillomavirus." Essay question }\end{array}$ \\
\hline $\begin{array}{l}\text { The association } \\
\text { between HPV and sex }\end{array}$ & $\begin{array}{l}\text { "I think that at a certain age, these are thing we don't talk about. It's a little taboo, I think, so we talk less freely." ITW3 } \\
\text { "Because this cancer is essentially due to frequent sexual activity, not necessarily healthy and not considering myself promiscuous, I don't think } \\
\text { it's necessary." Essay question }\end{array}$ \\
\hline Fear of side effects & $\begin{array}{l}\text { "Moreover, many girls .../... have become sterile or paralyzed." Essay question } \\
\text { "All the people I know who have done it had, for example, toe necrosis." Essay question } \\
\text { "They told me it might have permanent effects on the body..." Essay question } \\
\text { "[My friends] say the vaccine is more dangerous than the disease." Essay question } \\
\text { "I think we have to wait at least } 3 \text { generations to see if it's effective, and it's necessary to verify that the person who was vaccinated had } \\
\text { children and that it didn't have any effects on the children." ITW5 }\end{array}$ \\
\hline
\end{tabular}




\begin{tabular}{|c|c|}
\hline \multicolumn{2}{|r|}{ Adolescents' involvement in the vaccination decision } \\
\hline $\begin{array}{l}\text { A decision imposed by } \\
\text { the parents or physician }\end{array}$ & $\begin{array}{l}\text { "My mother decided to have me vaccinated." Essay question } \\
\text { "I'm not the one who made this decision." Essay question } \\
\text { "My parents made this decision on the doctor's advice." Essay question } \\
\text { "My mother talked to me about it and made me do it." Essay question } \\
\text { "No, I didn't really have a choice Essay question }\end{array}$ \\
\hline $\begin{array}{l}\text { Adolescents' passivity } \\
\text { in the face of the } \\
\text { parents' decision }\end{array}$ & $\begin{array}{l}\text { "I agreed, but I'm not really sure why." Essay question } \\
\text { "My parents refused, I didn't really worry about it." Essay question } \\
\text { "My GP and my parents were for it, so I agreed very easily without really know exactly what it was." Essay question }\end{array}$ \\
\hline $\begin{array}{l}\text { Active re-appropriation } \\
\text { by the adolescent }\end{array}$ & $\begin{array}{l}\text { "I trust my mother and my doctor, who I've known a long time." Essay question } \\
\text { "I'm against it, as is my doctor." Essay question } \\
\text { "I decided not to be vaccinated." Essay question }\end{array}$ \\
\hline \multicolumn{2}{|c|}{ The need for information and solutions } \\
\hline $\begin{array}{l}\text { The doctor, principal } \\
\text { source of information }\end{array}$ & $\begin{array}{l}\text { "My pediatrician talked about a vaccine against cervical cancer." Essay question } \\
\text { "My pediatrician explained a little bit to me about the papillomavirus vaccine." ITW4 }\end{array}$ \\
\hline $\begin{array}{l}\text { The need to provide } \\
\text { better information }\end{array}$ & $\begin{array}{l}\text { "Everyone says that you need to be vaccinated, without explaining why or what that might involve." Essay question } \\
\text { "It might be better to inform women about the beneficial effects of the vaccine, with real proof, that would be reassuring." Essay question } \\
\text { "They explain what puberty is, what periods are, they talk about sexually transmitted infections, but more about AIDS than about } \\
\text { papillomavirus." ITW1 }\end{array}$ \\
\hline Information in schools & $\begin{array}{l}\text { "It would be good to inform young people more about this vaccine, in more depth, especially in high schools, and do what's necessary to make } \\
\text { high school students interested in this subject." Essay question } \\
\text { "To start with, they need more interventions in schools and middle schools." ITW4 }\end{array}$ \\
\hline $\begin{array}{l}\text { Criticisms and } \\
\text { proposals }\end{array}$ & $\begin{array}{l}\text { "There are posters sometimes in doctors' waiting rooms, but we don't necessarily look at them!" ITW2 } \\
\text { "Maybe make an ad campaign on TV, like advertising but with messages about vaccination." ITW3 } \\
\text { "Why not make a character or mascot based on HPV; that would be not bad at all!" ITW2 }\end{array}$ \\
\hline
\end{tabular}

